Abstracta Iranica Abstranica

Revue bibliographique pour le domaine irano-aryen

Volume 40-41 | 2019

Comptes rendus des publications de 2017-2018

\title{
Omar Coloru. "Once were Persians: The Perception of Pre-Islamic Monuments in Iran from the 16th to the 19th Century"
}

\section{Olivia Ramble}

\author{
(2) OpenEdition \\ Journals \\ Édition électronique \\ URL : http://journals.openedition.org/abstractairanica/49812 \\ DOI : 10.4000/abstractairanica.49812 \\ ISBN : 1961-960X \\ ISSN : 1961-960X \\ Éditeur : \\ CNRS (UMR 7528 Mondes iraniens et indiens), Éditions de l'IFRI
}

Référence électronique

Olivia Ramble, « Omar Coloru. "Once were Persians: The Perception of Pre-Islamic Monuments in Iran from the 16th to the 19th Century" », Abstracta Iranica [En ligne], Volume 40-41 | 2019, document 11 , mis en ligne le 30 décembre 2019, consulté le 18 avril 2021. URL : http://journals.openedition.org/ abstractairanica/49812 ; DOI : https://doi.org/10.4000/abstractairanica.49812

Ce document a été généré automatiquement le 18 avril 2021

Tous droits réservés 
Omar Coloru. "Once were Persians: The Perception of Pre-Islamic Monuments in Iran from the 16th to the 19th Century"

Olivia Ramble 


\section{RÉFÉRENCE}

Omar Coloru. "Once were Persians: The Perception of Pre-Islamic Monuments in Iran from the 16th to the 19th Century" in Rolf Strootman, Miguel John Versluys (eds.). Persianism in Antiquity. Stuttgart: Franz Steiner, 2017, p. 86-106 (Oriens et Occidens 25)

1 L'A. explore le rôle du phénomène de "persianisme ", concept auquel est dédié cet ouvrage collectif, dans la construction des traditions locales autour des vestiges préislamiques de l'Iran, telles quelles sont rapportées par les voyageurs européens du XVIe au XIXe siècles- or eux-mêmes sont imprégnés des a priori dictés par l'historiographie grecque. Il distingue les traditions se rapportant: aux Achéménides, dont une mémoire floue, avec le nom de Dārā, a survécu par le filtre de la tradition nationale sassanide; aux Sassanides, qui, par le biais de la littérature (Shahnameh, Khosrow et Shirin) ont marqué la toponymie (ex: Bishapour); à la religion (le zoroastrisme mais aussi le judaïsme et le christianisme) avec l'attribution de sites aux 'rois guèbres', à Salomon ou David, ainsi qu'à la magie-les inscriptions cunéiformes notamment, associées dans l'imaginaire collectif aux zoroastriens, seraient la clé des trésors enfouis sous les ruines. Les «persianismes» prennent ici la forme de rois légendaires et de mythes fantastiques, faisant davantage état pour l'A. d'une évolution de traditions anciennes sur le long terme que d'une renaissance orchestrée de topoi du passé iranien.

\section{AUTEURS}

\section{OLIVIA RAMBLE}

Doctorante EPHE, Mondes iranien et indien, Paris 